\title{
Spatially explicit quantification of the interactions among ecosystem services
}

\author{
Yingjie Li $\cdot$ Liwei Zhang $\bullet$ Jiangxiao Qiu · Junping Yan · Luwen Wan • \\ Pengtao Wang $\cdot$ Ningke Hu $\cdot$ Wei Cheng $\cdot$ Bojie Fu
}

Received: 6 July 2016/Accepted: 30 April 2017/Published online: 10 May 2017

(C) Springer Science+Business Media Dordrecht 2017

\begin{abstract}
Context Human demands for ecosystem services (ES) have tremendously changed the landscape and led to degradation of ecosystems and associated services. The resolving of current eco-environmental problems calls for better understanding of the spatially explicit ES interactions to guide targeted landuse policy-making.

Objectives We propose a framework to map ES in continuous time-series, based on which we further quantify interactions among multiple ES.

Methods The supply of three key ES-soil conservation (SC), net primary production (NPP) and water yield (WY) - were quantified and mapped at fineresolution from 2000 to 2013 using easily-accessible
\end{abstract}

Electronic supplementary material The online version of this article (doi:10.1007/s10980-017-0527-6) contains supplementary material, which is available to authorized users.

Y. Li · L. Zhang $(\bowtie) \cdot$ J. Yan · P. Wang $\cdot$ N. Hu Department of Geography, Tourism and Environment College of Shaanxi Normal University, Xi'an,

Shaanxi 710119, China

e-mail: zlw@snnu.edu.cn

Y. Li

e-mail: lyj@snnu.edu.cn

J. Qiu

Fort Lauderdale Research and Education Center, Institute of Food and Agricultural Sciences, School of Forest

Resources and Conservation, University of Florida, Davie, FL 33314, USA spatial data. Pairwise ES interactions were quantified using a spatio-temporal statistical method.

Results Spatio-temporal analyses of ES dynamics illustrated that the supply of the three ES increased over the past 14 years in northern Shaanxi, where land cover dramatically changed owing to the wide-range ecological restoration projects. Our results also revealed that ES interactions varied across locations due to landscape heterogeneity and climate difference. In the arid and semi-arid area, synergies among ES (e.g., SC vs. WY) tended to dominate in grassland, while in artificial lands ES were prone to show tradeoffs. In the semi-humid area, pairwise ES (e.g., NPP vs. WY) in woodland tended to present synergies.

Conclusions The spatio-temporal variation of ES and their interactions resulted from coupling effect of human-induced climate and land-use change. In the long-term, spatially explicit quantification of ES

L. Wan

School of Geography, South China Normal University, Guangzhou, Guangdong 510631, China

W. Cheng · B. Fu

State Key Laboratory of Urban and Regional Ecology, Research Center for Eco-Environmental Sciences, Chinese Academy of Sciences, Beijing 100085, China 
interactions can help identify spatial heterogeneity in ES trade-offs and synergies, and inform regional targeted land-use policy adjustment and sustainable ecosystem management.

Keywords Multiple ecosystem services · Trade-off Synergy $\cdot$ Temporal dynamics $\cdot$ Spatial heterogeneity Partial correlation $\cdot$ LULC change $\cdot$ Loess Plateau

\section{Introduction}

Ecosystem services (ES), the benefits that humans obtain from ecosystems, have been mainstreamed into land-use planning and management (Daily et al. 2009; de Groot et al. 2010; Hu et al. 2014). Generally, ES are grouped into provisioning (e.g., food, fresh water, fiber and fuel), regulating (e.g., climate regulation, water purification), cultural (e.g., aesthetic, recreation) and supporting (e.g., primary production) services (MEA 2005). In recent years, the conflicts between the ever-growing human demands and limited resources have increasingly stood out. More directly, some ES such as provisioning services are prioritized due to their critical roles in the delivery of goods and services to support the human society, while other services such as regulating and cultural services are neglected or unintentionally impaired (Bennett et al. 2009; Haase et al. 2012; Deng et al. 2016). Therefore, it is urgent to understand and manage relationships among ES in order to protect multiple ES simultaneously and meanwhile maximize the benefits (Li 2014). Relationships among ES can be manifested as trade-off or synergy (Rodriguez et al. 2006). Trade-off occurs as the supply of one service is enhanced at the cost of reducing the supply of another, while synergy arises when multiple services are enhanced simultaneously (Rodriguez et al. 2006).

Significant progress has been made to quantify ES interactions across broad regions by analyzing the spatial overlap and relationships among multiple ES (Qiu and Turner 2013; Su and Fu 2013; Tomscha and Gergel 2016). The spatial overlap is often quantified using correlation analysis. The correlation coefficient as an ES interaction indicator for a region is calculated using either aggregated ES data sequence for geographical units (e.g., sub-basins, counties, grids) or random sampling points data across the whole region
(Anderson et al. 2009; Qin et al. 2015; Qiu and Turner 2015), and positively correlated ES are assumed to be synergistic whereas negative correlations are considered as trade-offs (Tomscha and Gergel 2016). This method can inform dominated relationships among ES, but could mask the spatial heterogeneity in ES interactions since the drivers (e.g., climate, LULC, and etc.) of ES change are often heterogeneous across a large landscape (Haase et al. 2012; Tomscha and Gergel 2016). Thereby, the results may lead to misinterpretation of ES interactions (Naidoo et al. 2008; Tomscha and Gergel 2016).

There are also other methods, such as multivariate statistics (principal component analysis, cluster and factor analysis) (Maes et al. 2012; Qiu and Turner 2013; Lee and Lautenbach 2016) and comparison in flower or spider web diagrams (Foley et al. 2005; Raudsepp-Hearne et al. 2010; Birkhofer et al. 2015; Renard et al. 2015) that were frequently applied in the analysis of ES interactions by identifying ES bundles (i.e., ES that tend to occur together). In addition, scenario analysis has also been proven as another promising pathway to analyze ES trade-offs (Nelson et al. 2009; Butler et al. 2013; Thompson et al. 2016). By developing alternative land use scenarios and then simulating plausible future conditions of ES, this method can assist stakeholders to evaluate the ES trade-offs as a result of management (Bennett 2017). Though future scenarios can help improve the landuse policy-making, understanding ES relationships from historical perspective is also important, especially for informing mechanisms behind ES relationships and also legacies persist over time. Moreover, a growing number of research emphasizes that historical perspective and time-series-based analyses to ES management is essential, especially in fast changing ecosystems (Dallimer et al. 2015). However, rarely have historical dynamic (or temporal change) been incorporated into understanding the ES interactions (but see Haase et al. 2012; Renard et al. 2015; Tomscha and Gergel 2016). Haase et al. (2012) analyzed the ES interactions by checking ES change over time (e.g., $\triangle E S$, the change of ES between the year 1990 and 2006): both positive change of pairwise ES is taken as synergy, and both negative change is seen as loss; otherwise, trade-offs. Spatial map approach is also used to identify and localize areas of change in ES synergies and trade-offs ( $\mathrm{Su}$ and $\mathrm{Fu}$ 2013; Renard et al. 2015), for example, using 
snapshots of ES supply at a single point in time (also called a space-for-time approach, see Tomscha and Gergel 2016) to reveal ES interactions over time. In another example, Tomscha and Gergel (2016) compared space-for-time approach and change-over-time approach, and pointed out the space-for-time approach may lead to contrasting characterizations of ES interactions while the change-over-time approach that incorporating long-term historical data and determining correlations in $\triangle \mathrm{ES}$ could better reveal ES temporal relationships in addition to spatial relationships. Nevertheless, the change-over-time approach may not adequately capture complex ES interactions, since it cannot identify spatially explicit ES relationships (like Haase et al. 2012). Thus, this approach may not be suitable for region characterized with heterogeneous landscapes. Moreover, the using of ES data at only two time points or several intervals may lead to some uncertainties. For example, extreme environmental disturbance (e.g., rainfall) in one year may contribute an extreme change in one certain service (e.g., water yield) while just a moderate change in another service (e.g., carbon sequestration) compared with a normal year; consequently, this abrupt change in one service will make the comparison of pairwise ES change unrepresentative. Renard et al. (2015) and Tomscha and Gergel (2016) also suggested that the identification of ES interactions should include longterm monitoring and baseline reconstructions of ES.

In other words, ES trade-offs and synergies can occur spatially (across locations) or temporally (over time) (Rodriguez et al. 2006), however, few studies have taken spatial-temporal dynamics of ES into analyzing ES interactions. In this study, we proposed a spatio-temporal statistical method for quantifying spatially explicit ES interactions. By integrating historical, continuous spatial datasets and spatial statistics into the analysis, this method may have the potential of moderating the aforementioned issues. Furthermore, this method would be particularly applicable to planning purposes at multiple-extent region (e.g., urban, regional, national, and global) where undergone heterogeneous and rapid changes in social, economic and environmental drivers of ES supply (Haase et al. 2012). Spatially refined ES in a continuous time series was estimated by synthesizing land use/land cover (LULC), topography (i.e., DEM) and remote sensing data (e.g., NDVI). Spatially explicit ES interactions are quantified using the spatial statistics method. Specifically, we selected three key ES (i.e., soil conservation, net primary production and water yield) of Shaanxi province in central-western China as a case. Based on the framework proposed (Fig. 1), we focused our analysis at fine-scale to address three research questions: (1) How the ES change over time, and where are areas of high and low supply of individual ES? (2) Where on the landscape are the interactions among ES located? (3) How the spatially explicit ES analytical framework can guide the ecosystem management and land-use decision-making?

\section{Methods}

Study area

Shaanxi province lies in $105^{\circ} 29^{\prime}-110^{\circ} 15^{\prime} \mathrm{E}, 31^{\circ} 42^{\prime}-$ $39^{\circ} 35^{\prime} \mathrm{N}$ (Fig. 2), covers approximately $205,800 \mathrm{~km}^{2}$ and had a resident population of $\sim 38$ million by the end of 2015. Characterized by mainland monsoon climate, the annual precipitation decreases from south to north: in the Hanjiang River basin, the annual precipitation is about $1000 \mathrm{~mm}$, whereas in the Qinling Mountain zone it reduces to $800 \mathrm{~mm}$, and in sandwindy plateau zone is only $400 \mathrm{~mm}$. Shaanxi plays an important eco-hydrological function role in China, since it locates in the middle of both the Yellow River basin (62.6\% of Shaanxi's area) and the Yangtze River basin (35.4\% of Shaanxi's area). Besides, approximately $40 \%$ of Shaanxi is in the Loess Plateau (LP), where intensive land use and degraded vegetation lead this area the most severe soil erosion in China ( $\mathrm{Su}$ et al. 2012). During the past decades, several ameliorative actions, such as the Three-North Shelter Forest Program (TNSFP) and the Grain-for-Green Program (GFG), have been launched by Chinese government to restore the vegetation and improve ecological environment. In addition to the great contribution of vegetation restoration and soil loss control, these ambitious and costly national-scale programs also led to the decrease in regional food production and water yield (Lü et al. 2012). In view of the distinct location and fragile ecoenvironment, along with the warming and drying climate over this semi-arid and arid region, it is pressing to distinguish the trade-offs among water (water yield), sediment (soil conservation) and carbon sequestration (net primary production) in order to better plan for further policy adjustment. 


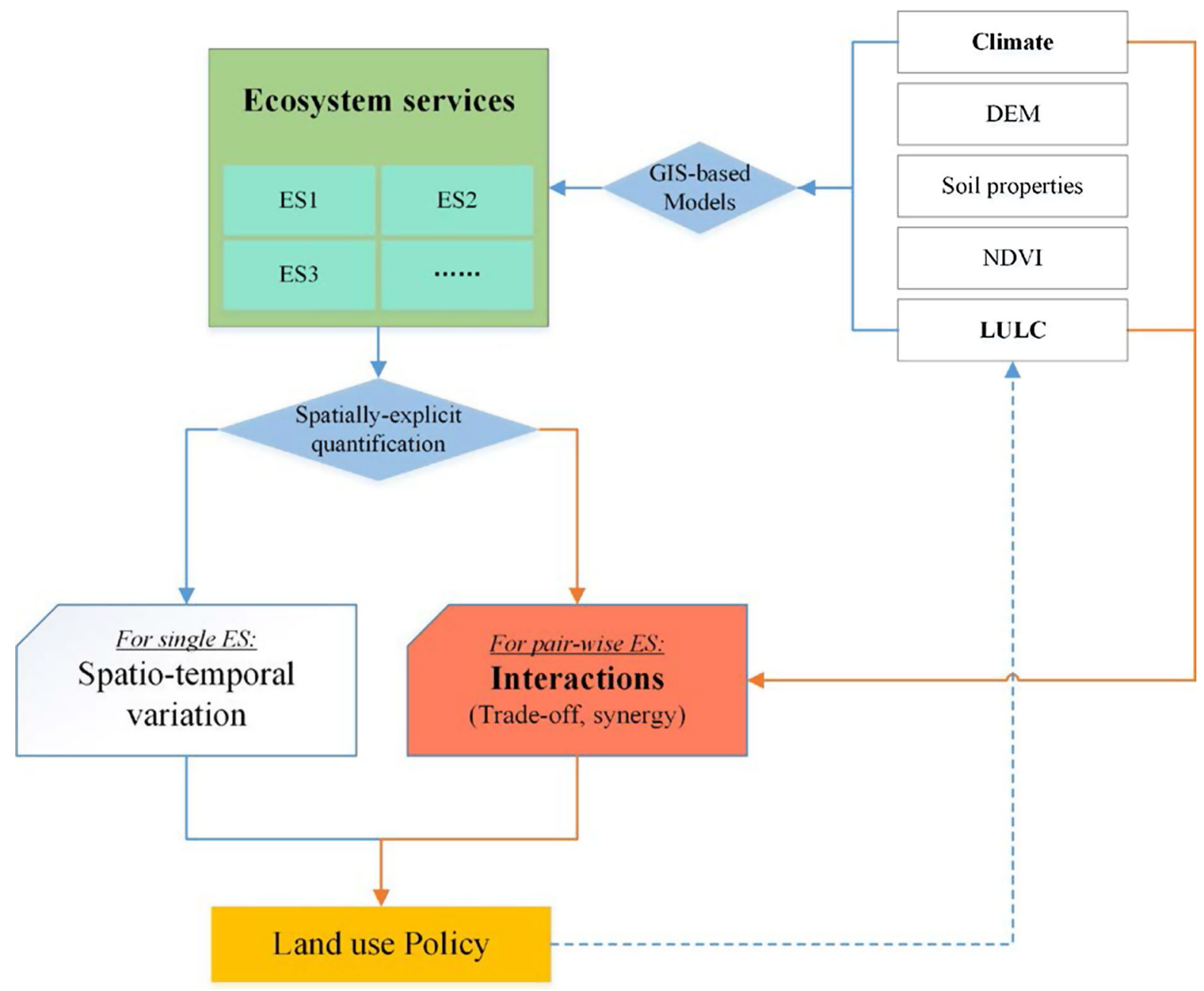

Fig. 1 The framework for integrating spatially explicit ES interactions to land-use policy-making

Datasets sources

The data used in modeling ES are listed in Table 1. The daily meteorological data (precipitation, temperature and solar radiation) of 45 stations (Fig. 2) are retrieved from National Meteorological Information Center. Topographical parameters (i.e., DEM) are derived from Shuttle Radar Topography Mission (STRM) digital elevation data. The Chinese soil dataset come from the Harmonized World Soil Database version 1.1 (HWSD) (Fischer et al. 2008). The 250-m MODIS NDVI data were acquired from NASA's Earth Observing System. The LULC data are interpreted from the Landsat $5 \mathrm{TM}$ based on the classification methods of decision trees using ENVI 5.2 software, and the accuracy levels of land use maps were above $94 \%$ and thus meet the accuracy requirements of the ES mapping models (Wang et al. 2014). All the data are interpolated or resampled [all using resampling algorithm of nearest neighbor assignment, except the resampling of LULC, which using the majority resampling algorithm (ESRI 2013)] into 250-m resolution before input them into the models for further analysis (Fu et al. 2011; Zhang et al. 2015).

\section{Quantifying ecosystem services supply}

The three ES (i.e., soil conservation, net primary production and water yield) were quantified for Shaanxi province using validated spatial models. All services were mapped at 250-m spatial resolution from 


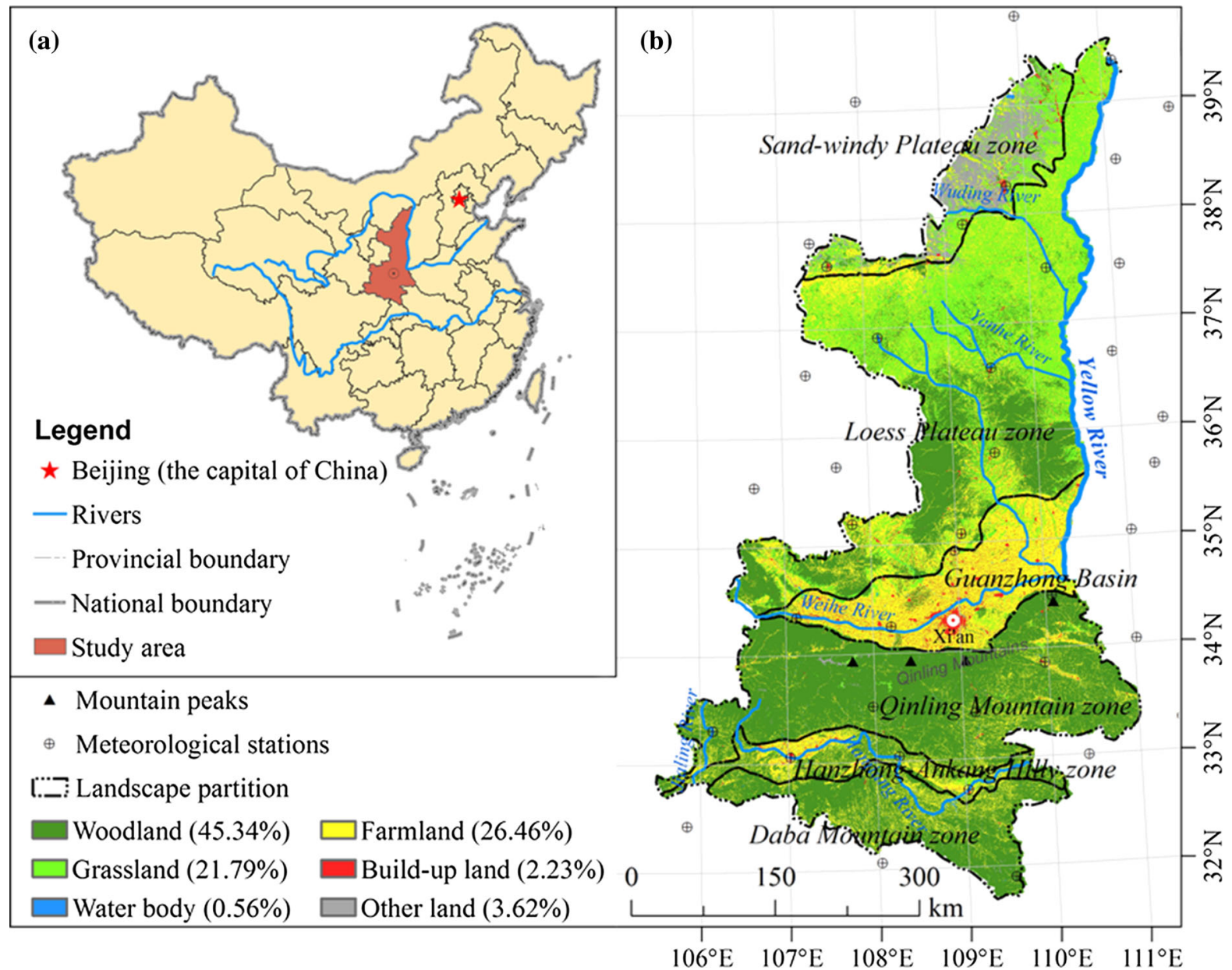

Fig. 2 The location of Shaanxi province in China (a); the geographical division and the LULC pattern (with area percent in 2013) of Shaanxi province (b)

Table 1 The datasets used for mapping ES

\begin{tabular}{lllll}
\hline Datasets & Data type & Spatial resolution & Time scale & Data sources \\
\hline Meteorological data & Point & - & $2000-2013$ & http://cdc.cma.gov.cn/ \\
Soil properties & Raster & $1 \mathrm{~km}$ & 2000 & http://westdc.westgis.ac.cn/data/ \\
DEM & Raster & $90 \mathrm{~m}$ & 2009 & http://www.gdem.aster.ersdac.or.jp/ \\
LULC & Polygon & $30 \mathrm{~m}$ & $2000,2005,2010,2013$ & http://www.landcover.org/data/ \\
MODIS NDVI & Raster & $250 \mathrm{~m}$ & $2000-2013$ & http://ladsweb.nascom.nasa.gov/data/ \\
\hline
\end{tabular}

2000 to 2013. Below we briefly summarized the approaches used for quantifying each service.

Soil conservation

Soil conservation (SC) is a critical regulating service supplied by terrestrial ecosystems to prevent soil erosion (Fu et al. 2011; Li et al. 2017). We apply the Revised Universal Soil Loss Equation (RUSLE) (Wischmeier and Smith 1965; Renard et al. 1997) to quantify soil erosion, and the wind erosion is neglected here since the Shaanxi province is dominated by water erosion (Fu et al. 2011). The soil conservation service can be estimated by the difference between potential 
erosion $\left(A_{p}\right)$ and real soil erosion $\left(A_{r}\right)$. The formula is defined as the following:

$S C=A_{p}-A_{r}$

$A_{p}=R \times K \times L \times S$

$A_{r}=R \times K \times L \times S \times C \times P$

where $S C$ is the amount of soil conservation $\left(\mathrm{t} \mathrm{hm}^{-2}\right.$ year $\left.^{-1}\right)$; $R$ is rainfall erosivity factor $\left(\mathrm{MJ} \mathrm{mm} \mathrm{hm} \mathrm{mm}^{-2} \mathrm{~h}^{-1} \cdot\right.$ year $^{-1}$ ); $K$ is soil erodibility factor ( $\mathrm{t} \mathrm{ha} \mathrm{h} \mathrm{ha}{ }^{-1} \mathrm{MJ}^{-1} \mathrm{~mm}^{-1}$ ); $L$ is the slope length factor; $C$ is dimensionless crop and management factor (Cai et al. 2000); $P$ refers to conservation practice factor (Lufafa et al. 2003; Fu et al. 2011).

Net primary production

Terrestrial net primary production (NPP) quantifies the amount of atmospheric carbon fixed by plants and accumulated as biomass (Haberl et al. 2013). It is a fundamental supporting service that represents a measure of the solar energy captured by ecosystems and driving the overall functioning of the ecosystems (MEA 2005). It also governs the flow of many provision and regulation services, like climate regulation service and carbon sequestration (Costanza et al. 2007; Zurlini et al. 2014).

The NPP can be estimated by combining remote sensing on the vegetation index, land-cover and climate data across a relatively large spatial area. The terrestrial Carnegie Ames-Stanford Approach (CASA) was used to estimate the NPP of ecosystems (Potter et al. 1993).

$\operatorname{NPP}(x, t)=\operatorname{APAR}(x, t) \times \varepsilon(x, t)$

where $\operatorname{NPP}(x, t)$ is the net primary production of location $x$ at month $t, \operatorname{APAR}(x, t)$ is the canopyabsorbed incident solar radiation ( $\left.\mathrm{MJ} \mathrm{m}^{-2}\right)$, and $\varepsilon(x, t)$ is the light utilization efficiency $\left(\mathrm{g} \mathrm{C} \mathrm{MJ}^{-1}\right)$. For more details on the parameters calculation refer to Potter et al. (1993) and Zhu et al. (2006). Data needed for the CASA model include land cover, NDVI, and climate data (Table 1). The annual NPP $\left(\mathrm{g} \mathrm{C} \mathrm{m}^{-2}\right.$ year $\left.^{-1}\right)$ is the sum of monthly NPP within one year.

\section{Water yield}

Water is the most sensitive and limiting natural resource in semi-arid and arid region systems, and changes in LULC and climate can substantially impact the regional hydrological cycle by altering evapotranspiration processes (Zhang et al. 2001). In this study, the water yield was selected as an indicator of hydrological regulation ES (Lü et al. 2012; Jia et al. 2014; Sharp et al. 2016) that includes the maintenance of natural irrigation and drainage, buffering of extremes in discharge of rivers, and etc. (de Groot et al. 2002). Regional annual water yield (WY) is mostly determined by annual precipitation (PPT) and actual evapotranspiration (ET) (Budyko 1974; Feng et al. 2012) with the assumption that the soil water storage change $(\Delta S)$ is negligible at regional and longtime scales (Zhang et al. 2004). Annual actual ET was estimated by using by Zhang et al. (2001)'s empirical model. This model was calibrated using hydrologic data from over 250 watersheds worldwide across a wide range of climatic zones and biomes (Zhang et al. 2001; Sun et al. 2006), and has been validated in many case studies to be reliable to evaluate regional water yield over a long time period (Zhang et al. 2012, 2015; Lu et al. 2013). The water yield is calculated using the following formulas:

$W Y=P P T-E T \pm \Delta S$

$E T=\frac{1+\mathrm{w} \frac{P E T}{P P T}}{1+\mathrm{w} \frac{P E T}{P P T}+\frac{P P T}{P E T}} \cdot P P T$

where PET represents annual potential evapotranspiration $(\mathrm{mm})$, which was calculated using daily meteorological data and Hamon PET method (Hamon 1963); $w$ is the plant-available water coefficient and it represents the relative difference in the way plants use soil water for transpiration (Zhang et al. 2001). According to the published literatures in China (Sun et al. 2005; Zhao et al. 2012; Lu et al. 2013; Zhang et al. 2015), the $w$ parameter values (see Table 2) were assigned as 2.0 for high-cover woodland (where forest cover $>30 \%$ ), 1.0 for low-cover woodland (where forest cover $<30 \%$ ), 1.0 for shrubland, 0.5 for grassland and cropland, and 0.1 for artificial and barren land. ET for water body was defined as the minimum of $P$ and $P E T$, i.e., $E T=\operatorname{Min}(P, P E T)(\mathrm{Lu}$ et al. 2013). For the limited LULC data (in 2000, 2005, 2010 and 2013), we used the LULC data in 2000 to model the WY for the initial year of 2000, LULC data in 2005 to model the WY during 2001 to 2005, LULC data in 2010 to model the WY during 2006 to 2010, 
and LULC data in 2013 to model the WY during 2011 to 2013. This assignment is based the assumption that the changes in LULC during the five-year intervals are small, because the major land use change was regular in line with the Five-Year Plan of China (Liu et al. 2014).

\section{Analyzing ecosystem services interactions}

The quantification of interactions among pairwise ES was based on the overlay analysis (Fig. 3a). To avoid the cross-influence of other confounding factors (e.g., the synchronous change of climate and LULC; and in this study, we chose two surrogate factors, i.e., $r_{3}-$ annual precipitation and $r_{4}$-annual NDVI), we employed the partial correlation analysis to measure the correlativity between pairwise ES. The calculation was performed by MATLAB 8.1 programming, and the corresponding formulas are defined as the following:

$\mathrm{r}_{12 \cdot 34(i j)}=\frac{\mathrm{r}_{12 \cdot 3(i j)}-\mathrm{r}_{14 \cdot 3(i j)} \mathrm{r}_{24 \cdot 3(i j)}}{\sqrt{\left(1-\mathrm{r}_{14 \cdot 3(i j)}^{2}\right)\left(1-\mathrm{r}_{24 \cdot 3(i j)}^{2}\right)}}$

$$
\mathrm{r}_{12(i j)}=\frac{\sum_{n=1}^{\mathrm{n}}\left(E S 1_{n(i j)}-\overline{E S 1_{(i j)}}\right)\left(E S 2_{n \cdot(i j)}-\overline{E S 2_{(i j)}}\right)}{\sqrt{\sum_{n=1}^{n}\left(E S 1_{n \cdot(i j)}-\overline{E S 1_{(i j)}}\right)^{2} \sum_{n=1}^{n}\left(E S 2_{n \cdot(i j)}-\overline{E S 2_{(i j)}}\right)^{2}}}
$$

where $r_{12.34(i j)}$ is the partial correlation coefficient between ES1 and ES2 under the condition that $r_{3}$ (annual precipitation) and $r_{4}$ (annual NDVI) are controlled for grid cell $i j ; n$ is the year and $i, j$ the grid cell for certain ES in one year, for example, $\mathrm{ES}_{1 .(13)}$ represents the grid cell whose value is 8 in Fig. 3a; Similarly, other parameters like $r_{12.3(i j)}$ is the partial correlation coefficient between ES1 and ES2 by controlling $r_{3}$ for the grid cell $i j$; the $r_{12(i j)}$ is the correlation coefficient between $\mathrm{ES} 1_{n \cdot i j}$ and $\mathrm{ES} 2_{n \cdot i j}$.

This method can quantify and map the magnitude and spatial patterns of ES interactions with a more visualized understanding of ES interactions comparing with conventional methods (see examples in Fig. 3b, c).

Comparison of the methods for ecosystem services interactions

We compared the existing methods of quantifying ES interactions (Table 3). For the spatio-temporal statistical

Table 2 The empirical parameter of the plant-available water coefficient $(w)$ frequently adopted in different case study

\begin{tabular}{|c|c|c|c|c|c|c|c|c|}
\hline \multirow{3}{*}{$\begin{array}{l}\text { Land cover } \\
\text { Wood land }\end{array}$} & \multirow{3}{*}{$\begin{array}{l}\text { Worldwide } \\
\text { (Zhang et al. 2001) } \\
2.0\end{array}$} & \multirow{2}{*}{$\begin{array}{l}\text { Southeastern USA } \\
\text { (Sun et al. 2005) } \\
\begin{array}{l}\text { Conifer, deciduous and } \\
\text { hardwood }\end{array}\end{array}$} & \multirow[b]{2}{*}{2.8} & \multirow{2}{*}{$\begin{array}{l}\text { In northern } \\
\text { China (Zhao } \\
\text { et al. 2012) } \\
2.8\end{array}$} & \multicolumn{2}{|c|}{$\begin{array}{l}\text { In mid-eastern } \\
\text { China (Lu } \\
\text { et al. 2013) }\end{array}$} & \multicolumn{2}{|c|}{$\begin{array}{l}\text { In central- } \\
\text { western } \\
\text { China (This } \\
\text { paper) }\end{array}$} \\
\hline & & & & & $\begin{array}{l}\text { High- } \\
\text { cover }\end{array}$ & 2.0 & $\begin{array}{l}\text { High- } \\
\text { cover }\end{array}$ & 2.8 \\
\hline & & Mixed & 2.0 & & $\begin{array}{l}\text { Low- } \\
\text { cover }\end{array}$ & 1.0 & $\begin{array}{l}\text { Low- } \\
\text { cover }\end{array}$ & 2.0 \\
\hline Shrub land & - & & - & 1.0 & & 1.0 & & 1.0 \\
\hline Grassland & 0.5 & & 2.0 & 1.5 & & 0.5 & & 1.5 \\
\hline Crop land & 0.5 & & - & 1.5 & & 0.5 & & 1.5 \\
\hline $\begin{array}{l}\text { Artificial or urban } \\
\text { land }\end{array}$ & - & & 0.0 & 0 & & 0.1 & & 0.0 \\
\hline Barren land & $<0.5$ & & - & 0 & & 0.1 & & 0.0 \\
\hline $\begin{array}{l}\text { Wetland or water } \\
\text { bodies }\end{array}$ & - & $\mathrm{ET}=\min (\mathrm{PPT}, \mathrm{PET})$ & & & & & & \\
\hline Note: & $\begin{array}{l}1.0 \text { for mixed } \\
\text { vegetation }\end{array}$ & & & & & & & \\
\hline Validation & $\sqrt{ }$ & $\sqrt{ }$ & & $\sqrt{ }$ & $\sqrt{ }$ & & & \\
\hline
\end{tabular}




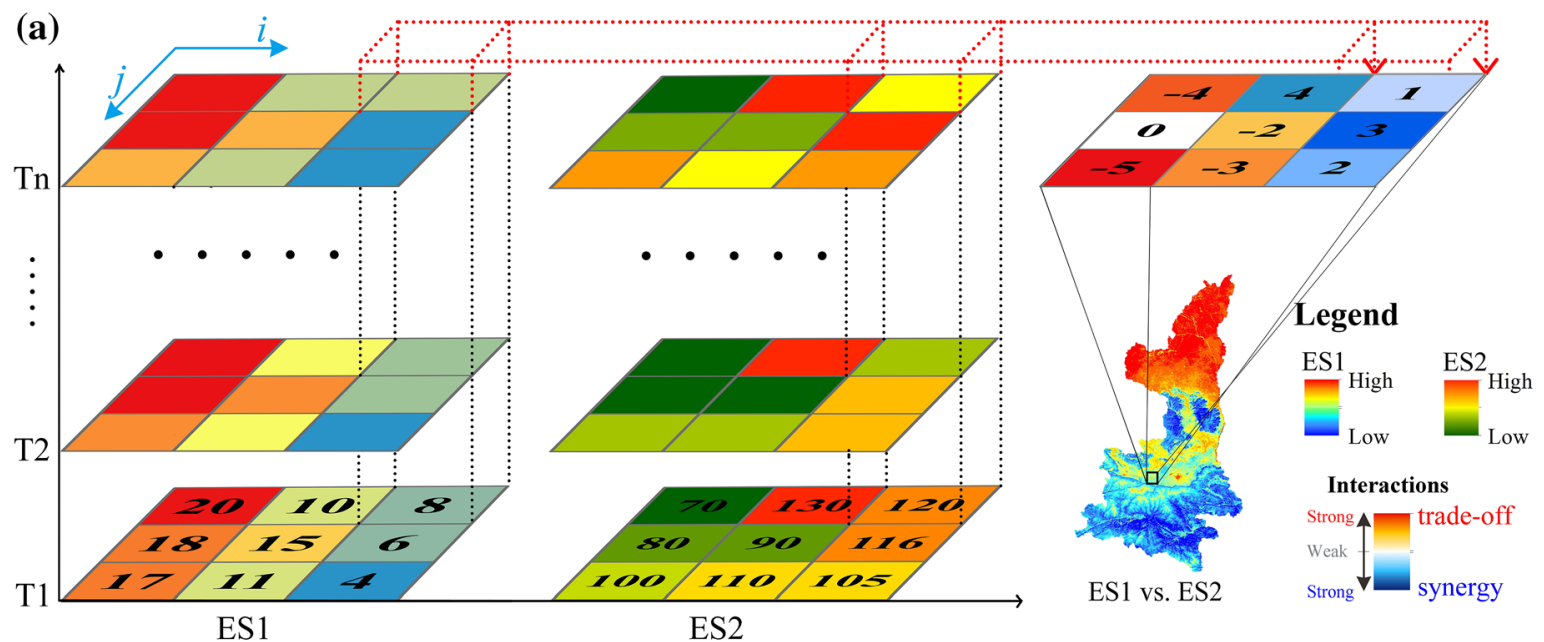

(b)

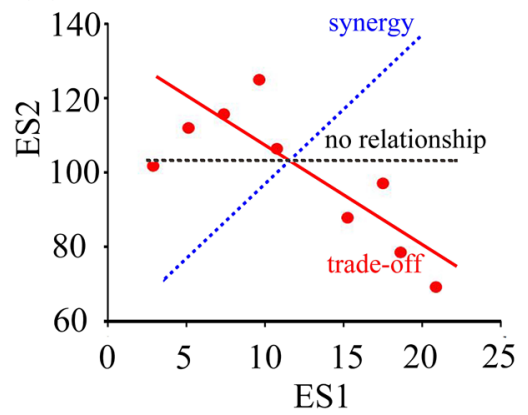

(c)

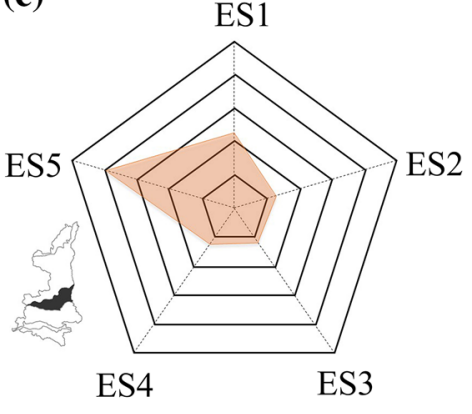

(d)

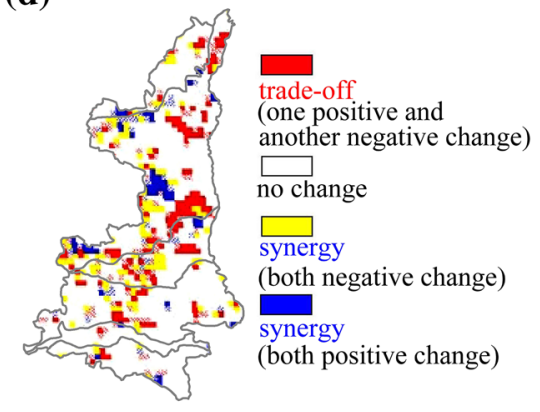

Fig. 3 Schematic diagram of the methods for analyzing ES interactions: a Spatio-temporal statistical method for quantifying ES interactions at fine spatio-temporal scale; b overall (or sampled) subregion-by-subregion (or cell-by-cell) correlation analysis between two services (in static manner), for example, negative correlation between ES1 and ES2 for the year of T1 indicates trade-off between ES1 and ES2 (the red solid line); $\mathbf{c}$ a

method, we merged the identified ES interactions at different significance levels into three categories (i.e., trade-off, synergy and no relationship) to test the agreement among the results mapped from other spatially explicit methods (i.e., methods $\mathrm{m} 5$ and $\mathrm{m} 6$ described in Table 3) by calculating Cohen's Kappa coefficients (Landis and Koch 1977; Schröter and Remme 2016).

\section{Results}

Spatio-temporal variations of ecosystem services

The annual total soil conservation (SC) and net primary production (NPP) of Shaanxi province both spider web diagram shows the relationships among multiple ES [adapted from (Ungaro et al. 2014), also in static manner]; $\mathbf{d}$ an temporal integration method using a change detection of pairwise ES interactions (e.g. biodiversity vs. carbon storage) of two time periods (i.e., the year of T1-T2) [adapted from (Haase et al. 2012)]

increased as a whole, while annual total water yield (WY) of this area decreased from 2000 to 2013 (Fig. 4). Apart from the steady and significant $(P<0.05)$ increase of SC, there were evident interannual fluctuations in the variation of both NPP and WY. Consequently, the relationships among ES may not be stable in each year (Renard et al. 2015). For example, from 2009 to 2010, SC increased significantly, NPP showed little change, while WY showed a dramatic decrease; however, from 2010 to 2011, SC and NPP both presented a small increase, while the WY showed a dramatic increase.

Production of all the three ES varied geographically (Fig. 5), and services were spatially aggregated rather than randomly distributed on the landscape 
Table 3 Comparison of methods for ES interactions

\begin{tabular}{|c|c|c|c|c|c|c|}
\hline No. & $\begin{array}{l}\text { Temporal } \\
\text { dynamic }\end{array}$ & $\begin{array}{l}\text { Spatial units in } \\
\text { calculation }\end{array}$ & Methods & $\begin{array}{l}\text { Apply } \\
\text { spatial scale }\end{array}$ & Examples & $\begin{array}{l}\text { Spatially } \\
\text { explicit }\end{array}$ \\
\hline \multirow[t]{4}{*}{ I } & \multirow[t]{4}{*}{ Static (1 year) } & \multirow[t]{2}{*}{$\begin{array}{l}\text { Sub-region (e.g. } \\
\text { counties, } \\
\text { municipalities) } \\
\text { or sub- } \\
\text { watershed }\end{array}$} & $\begin{array}{l}{ }^{\mathrm{m} 1} \text { Space-for-time approach: Overall } \\
\text { subregion-by-subregion } \\
\text { correlation (e.g., Fig. } 3 \text { b) }\end{array}$ & $\begin{array}{l}\text { Small } \\
\text { watershed } \\
\text { or local } \\
\text { scale }\end{array}$ & Extensively used & No \\
\hline & & & $\begin{array}{l}{ }^{\mathrm{m} 2} \text { Identify ES bundles or compare } \\
\text { the relative magnitude of multiple } \\
\text { ES supply (e.g., Fig. } 3 \mathrm{c} \text { ) }\end{array}$ & $\begin{array}{l}\text { Both small } \\
\text { scale and } \\
\text { broad } \\
\text { scale }\end{array}$ & $\begin{array}{l}\text { Foley et al. (2005), } \\
\text { Raudsepp-Hearne } \\
\text { et al. (2010), } \\
\text { Ungaro et al. } \\
\text { (2014) }\end{array}$ & Yes \\
\hline & & \multirow[t]{2}{*}{ Grid cell } & $\begin{array}{l}{ }^{\mathrm{m} 1} \text { Space-for-time approach: Overall } \\
\text { (or sampled) cell-by-cell } \\
\text { correlation }\end{array}$ & $\begin{array}{l}\text { Small } \\
\text { watershed } \\
\text { or local } \\
\text { scale }\end{array}$ & Jia et al. (2014) & No \\
\hline & & & $\begin{array}{l}\text { m3 Multivariate statistics (e.g., } \\
\text { principal component analysis, } \\
\text { cluster and factor analysis) on the } \\
\text { basis of sampled random grid cell }\end{array}$ & Watershed & $\begin{array}{l}\text { Qiu and Turner } \\
\text { (2013) }\end{array}$ & Yes \\
\hline \multirow[t]{2}{*}{ II } & \multirow[t]{2}{*}{$\begin{array}{l}\text { Semi-static (two } \\
\text { time points) }\end{array}$} & $\begin{array}{l}\text { Sub-region (e.g. } \\
\text { counties, } \\
\text { municipalities) } \\
\text { or sub- } \\
\text { watershed }\end{array}$ & $\begin{array}{l}{ }^{\mathrm{m}} \text { Change-over-time approach: } \\
\text { Overall subregion-by-subregion } \\
\text { correlations between pairwise ES } \\
\text { map differences (i.e., } \Delta \mathrm{ES} \text { from } \\
\text { two time points) }\end{array}$ & $\begin{array}{l}\text { Small } \\
\text { watershed } \\
\text { or local } \\
\text { scale }\end{array}$ & $\begin{array}{l}\text { Tomscha and } \\
\text { Gergel (2016) }\end{array}$ & No \\
\hline & & Grid cell & $\begin{array}{l}(※)^{\mathrm{m} 5} \text { Test the consistency of } \\
\text { pairwise ES change direction for } \\
\text { two time points (e.g., Fig. } 3 \mathrm{~d})\end{array}$ & $\begin{array}{l}\text { No } \\
\text { limitation }\end{array}$ & $\begin{array}{l}\text { This paper (Haase } \\
\text { et al. 2012) }\end{array}$ & Yes \\
\hline \multirow[t]{3}{*}{ III } & \multirow[t]{3}{*}{$\begin{array}{l}\text { Dynamic (at } \\
\text { several time } \\
\text { intervals or a } \\
\text { continuous } \\
\text { time series) }\end{array}$} & $\begin{array}{l}\text { Sub-region (e.g. } \\
\text { counties, } \\
\text { municipalities) } \\
\text { or sub- } \\
\text { watershed }\end{array}$ & $\begin{array}{l}{ }^{\mathrm{m} 1} \text { Space-for-time approach: } \\
\text { Spearman correlation among each } \\
\text { pair of ES for each time step to } \\
\text { assess changes of the ES } \\
\text { interactions over time }\end{array}$ & $\begin{array}{l}\text { Reginal } \\
\text { scale }\end{array}$ & Renard et al. (2015) & No \\
\hline & & Grid cell & $\begin{array}{l}(※)^{\mathrm{m} 6} \text { Test the consistency of the } \\
\text { change trend direction of pairwise } \\
\text { ES }\end{array}$ & $\begin{array}{l}\text { No } \\
\quad \text { limitation }\end{array}$ & This paper & Yes \\
\hline & & Grid cell & $\begin{array}{l}(※)^{\mathrm{m} 7} \text { Spatio-temporal statistical } \\
\text { method: (Partial) Correlations } \\
\text { between pairwise ES changing } \\
\text { over time (e.g., Fig. 3a) }\end{array}$ & $\begin{array}{l}\text { No } \\
\text { limitation }\end{array}$ & This paper & Yes \\
\hline
\end{tabular}

Methods $\mathrm{m} 1, \mathrm{~m} 4, \mathrm{~m} 5, \mathrm{~m} 6$ and $\mathrm{m} 7$ were selected to conduct comparison test in this study. Especially, methods marked with "( () " could delineate spatially explicit ES interactions (i.e., visualized maps of ES interactions) in addition to considering temporal dynamic in ES

$\mathrm{m} 5$ : both of the ES showing positive change indicates synergy; one showing positive change and the other negative change indicates trade-off

m6: the change trend for each ES was calculated in the least square method, and both of the ES showing positive change trend indicates synergy; one showing positive change and the other negative change indicates trade-off

m7: pairwise ES showing positive correlation over time indicates synergy, otherwise trade-off. See Fig. 3a for details about this method

$(P<0.001)$. The spatial patterns of SC, NPP and WY were similar with higher values in the south as compared to the north of Shaanxi province. The distinct boundary for this spatial pattern is the Qinling
Mountains, due to the significant differentiation in regional climatic, hydrothermal conditions and vegetation cover at its two sides of the mountains. Besides, the most significant change in the three ES occurred in 
the northern Yan River basin (i.e., the northern Loess Plateau in Shaanxi province). The SC and NPP of this area were much higher than the surrounding regions, and also undergone a significant increase over the past 14 years (Fig. 5). However, the WY in the same area showed an inverse spatial pattern compared with SC and NPP, that is, WY in the middle of Yan River basin was higher than the west and east (Fig. 5c). Interestingly, in the west-south of Shaanxi province, SC and WY both showed a significant increase trend, while the NPP here decreased significantly $(P<0.05)$. Thereby, the interactions among ES may differ across geographical locations or different landscapes (Rodriguez et al. 2006; Goldstein et al. 2012; Haase et al. 2012; Qiu and Turner 2013).

Spatial heterogeneity in ecosystem services interactions

Our spatio-temporal statistical method revealed that ES interactions varied across different locations (Fig. 6). For SC and NPP, strong synergies spatially aggregated in the northern LP, accounting for $2.12 \%$ of the landscapes, while strong trade-offs spatially occurred in the south of LP and Daba Mountains (DM) region, totally accounting for $3.49 \%$ of the landscapes. Spatial patterns of the interactions between SC and

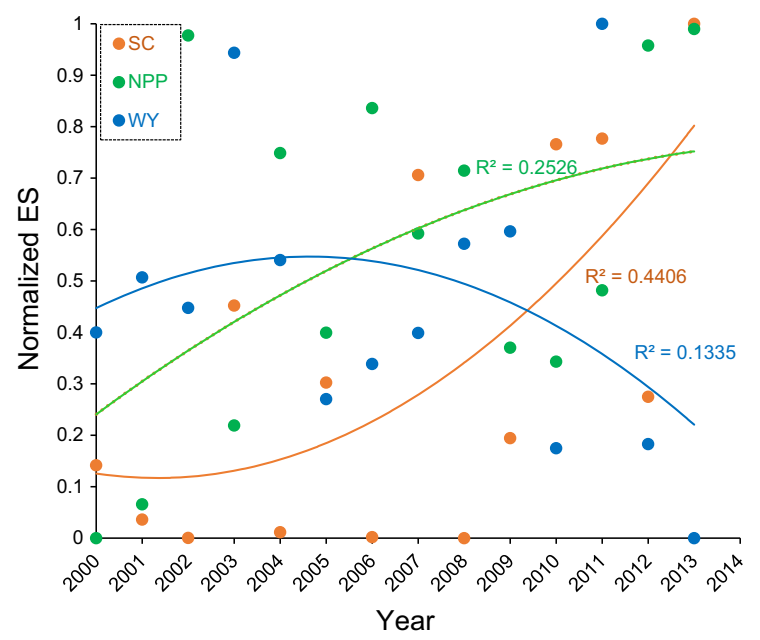

Fig. 4 The temporal dynamic of the three ES in Shaanxi province, China. We normalized the annual soil conservation (SC), net primary production (NPP) and water yield (WY) to $0-1$ (the points), and plotted their change trend from 2000 to 2013 (solid lines). SC and NPP showed increase trend, while WY presented decrease trend as a whole
WY were similar to the SC and NPP interaction. The most pronounced distinction was that, in the LP region, strong synergies between $\mathrm{SC}$ and WY accounted for $11.55 \%$ of landscapes (Fig. 6b). For the interactions between NPP and WY, the strong synergies also spatially aggregated in the northern LP, whereas the strong trade-offs occurred in the Guanzhong basin (GB), where covered by the most intensively managed croplands and most urban impervious surface (Figs. 2, 6c). Overall, synergies among the three ES mostly presented in the northern LP (vegetation-dominated landscapes, e.g., woodland and grassland), while trade-offs mostly occurred in the southern LP and GB (human-dominated landscapes, e.g., farmland and built-up land).

Ecosystem services interactions differ by land use/land cover types

To further detect whether the ES interactions have certain relations with LULC types, we calculated the proportions of each ES interactions type in each LULC type (Fig. 7). The results showed that ES interactions in grassland were prone to present synergies (more than $70 \%$ of the total grassland), while built-up land tended to show trade-offs (more than $60 \%$ of the builtup land) among all three pairwise ES. Other LULC types, such as woodland, water body, in which SC versus NPP and SC versus WY interactions tended to be trade-offs, but the NPP versus WY interrelation tended to be synergies in these LULC types. Thus, ES interactions differ by certain LULC types.

Comparison of the different methods for ES interactions analysis

Our brief review of methods indicated that static approaches (i.e., methods $\mathrm{m} 1, \mathrm{~m} 2$ and $\mathrm{m} 3$ described in Table 3) used to detect ES interactions usually assume the spatio-temporal variability of ES is comparable (Tomscha and Gergel 2016). Therefore, they usually concluded a definite or dominated relationship between pairwise ES. For example, employing methods $\mathrm{m} 1$ and $\mathrm{m} 2$ in our study showed that only strong synergies existed in the three ES (see Appendix 1, Table A1). However, the spatially explicit approaches (i.e., methods $\mathrm{m} 5, \mathrm{~m} 6$ and $\mathrm{m} 7$ described in Table 3) all revealed pronounced spatial heterogeneity in ES interactions. For instance, across the Shaanxi 
(a) $\mathrm{SC}$
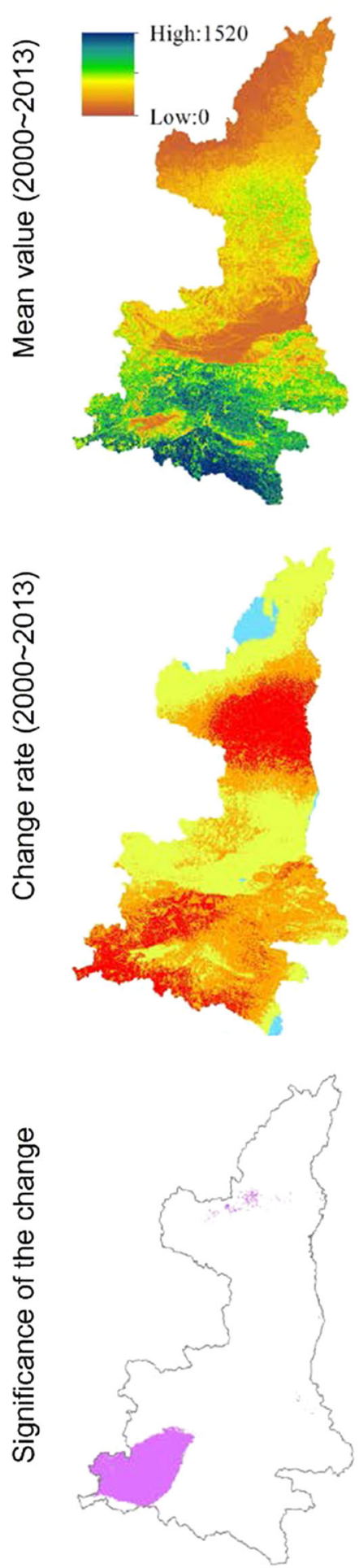

(b) NPP
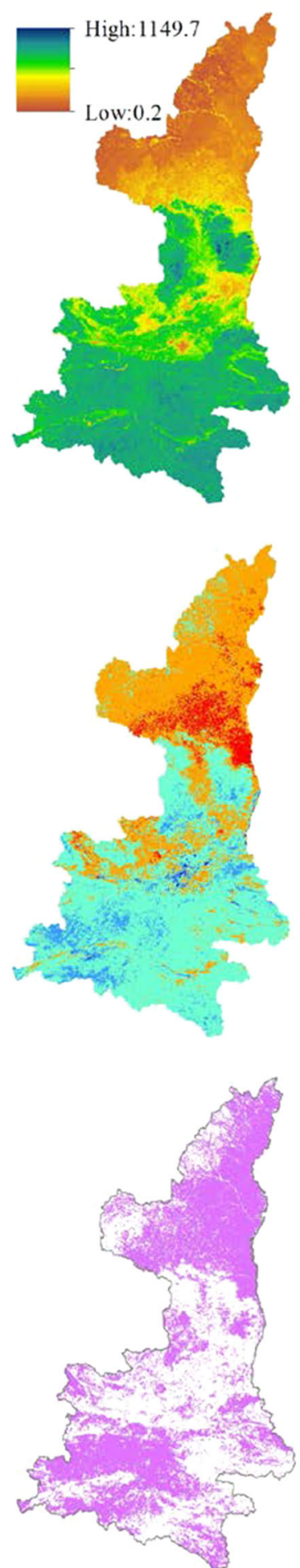

(c) WY
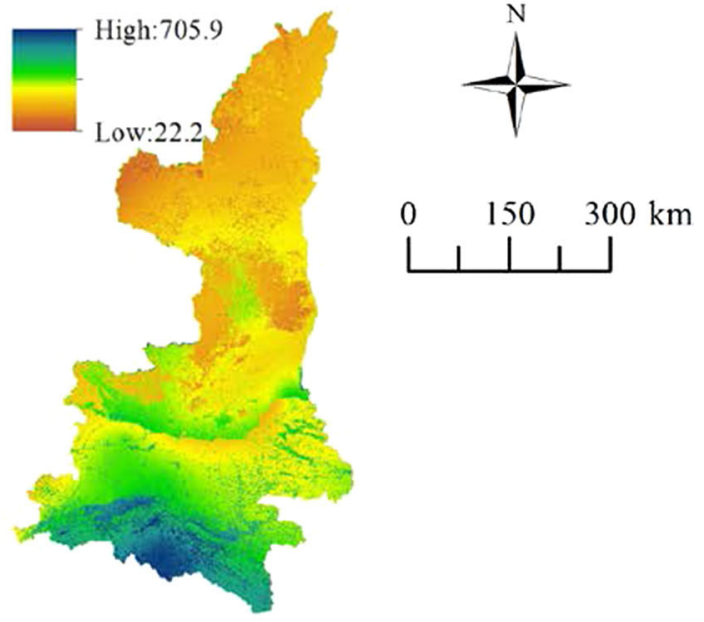

\section{Change rate}

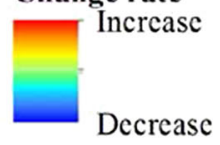

Significance level

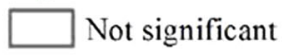

Significant

Fig. 5 Spatial patterns of the three ES' mean values, change trend and the significance level $(P<0.05)$ from 2000 to 2013 ; a soil conservation (SC), b net primary production (NPP) and $\mathbf{c}$ water yield (WY) 
Fig. 6 The spatial patterns of pairwise ES interactions (the left maps), and the proportions of each ES interaction in each landscape (the right bar charts). The quantitative relationships between pairwise ES is based on partial correlation analysis using MATLAB

programming. $* P<0.1$; $* * P<0.05$. The abbreviation of each landscape is showed below (in the order of north-tosouth): Sand-windy Plateau (SWP), Loess Plateau (LP), Guanzhong Basin (GB), Qinling Mountains region (QM), Hanzhong-Ankang Hilly region (HAH), Daba Mountains region (DM)
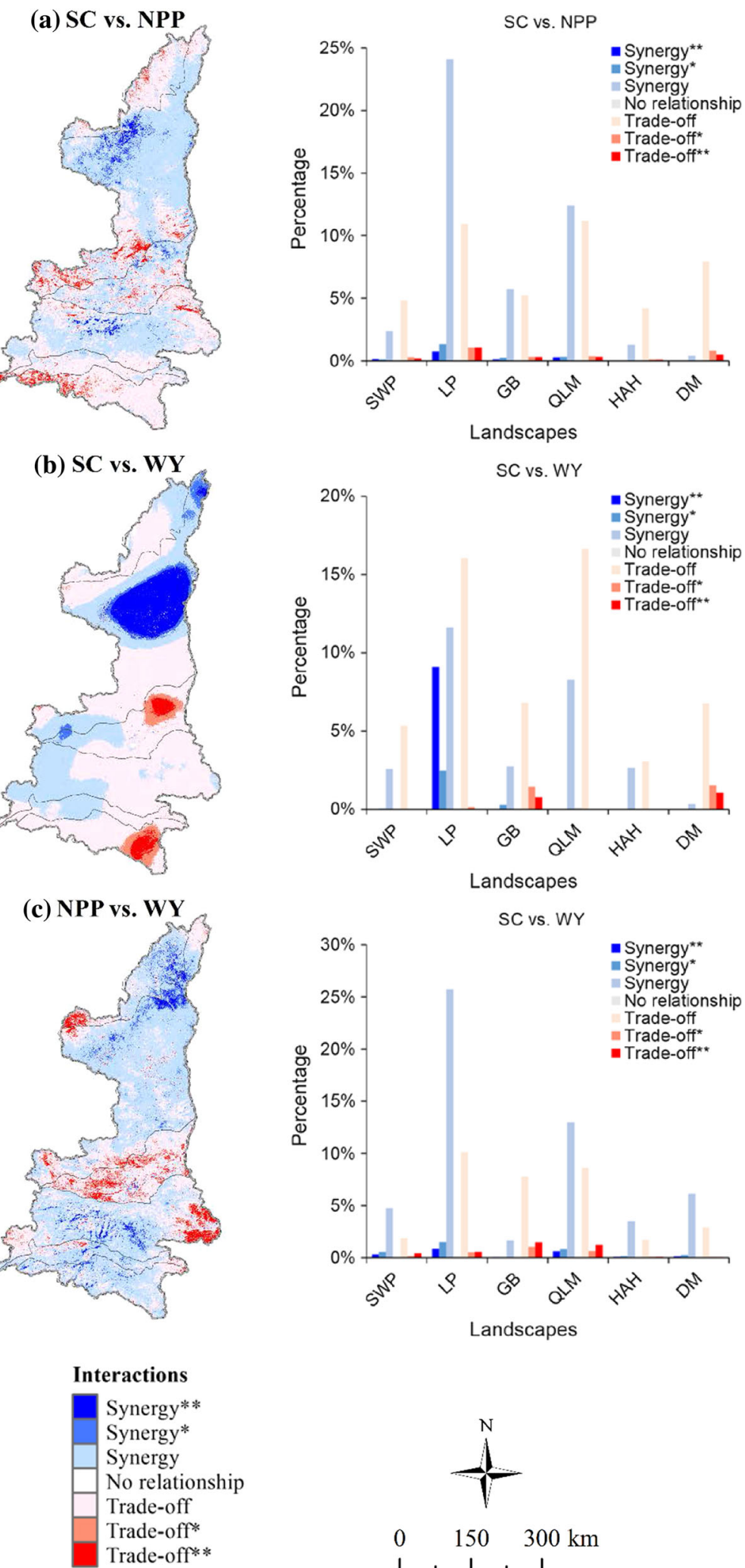
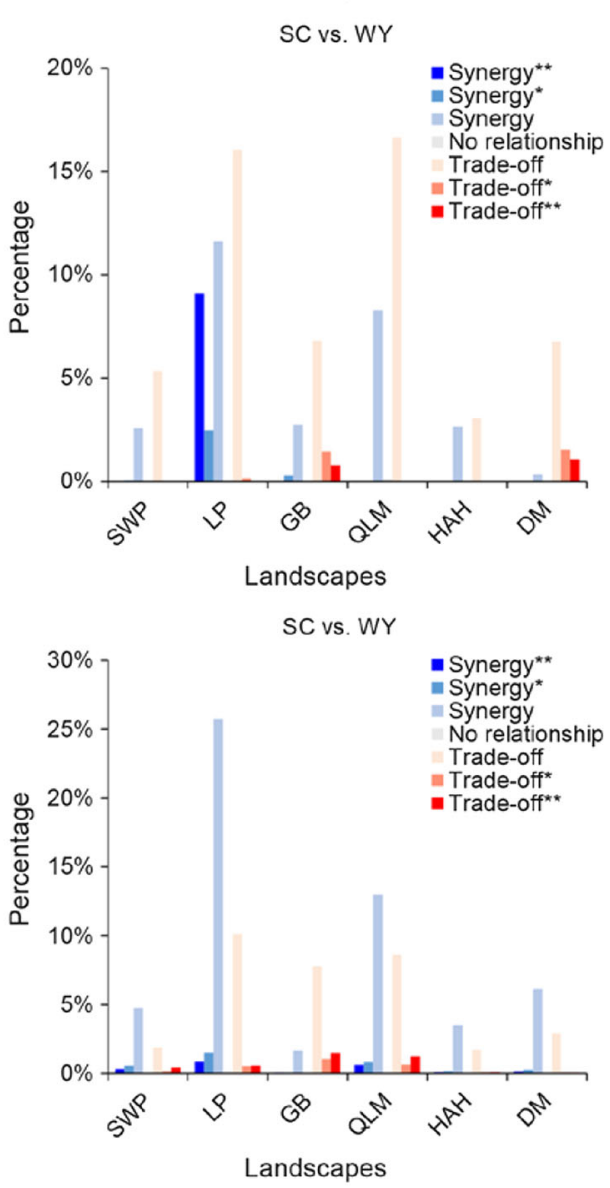
province, method $\mathrm{m} 7$ detected that $3.37 \%$ of the landscapes presented strong synergies, while $5.63 \%$ of the landscapes showed significant trade-offs between SC and NPP (see Fig. 6; Appendix 2, Fig. A1). In addition, the areas where weak synergies and tradeoffs between these two ES accounted for $46.38 \%$ and $44.39 \%$ of the landscapes respectively.

We further compared the three spatially explicit approaches (i.e., methods $\mathrm{m} 5, \mathrm{~m} 6$ and $\mathrm{m} 7$ ) using Kappa statistic (see Appendix 2, Fig. A2; Table 4). Kappa values close to 1 would indicate almost perfect agreement (Schröter and Remme 2016). Pairwise comparisons showed that fair agreement was observed between methods $\mathrm{m} 6$ and $\mathrm{m} 7$ for the interactions between SC versus NPP, SC versus WY. Specially, for $\mathrm{SC}$ versus NPP interaction, the methods $\mathrm{m} 6$ and $\mathrm{m} 7$ that using longer-term ES data showed moderate agreement $(K=0.44)$.

\section{Discussion}

Spatio-temporal variation in the ecosystem services and their drivers

Our study examined fine-scale spatial and temporal dynamics of three ecosystem service (ES), i.e., soil conservation (SC), net primary production (NPP) and
Fig. 7 The area proportion of ES interactions in each LULC type. $* P<0.1$; $* * P<0.05$

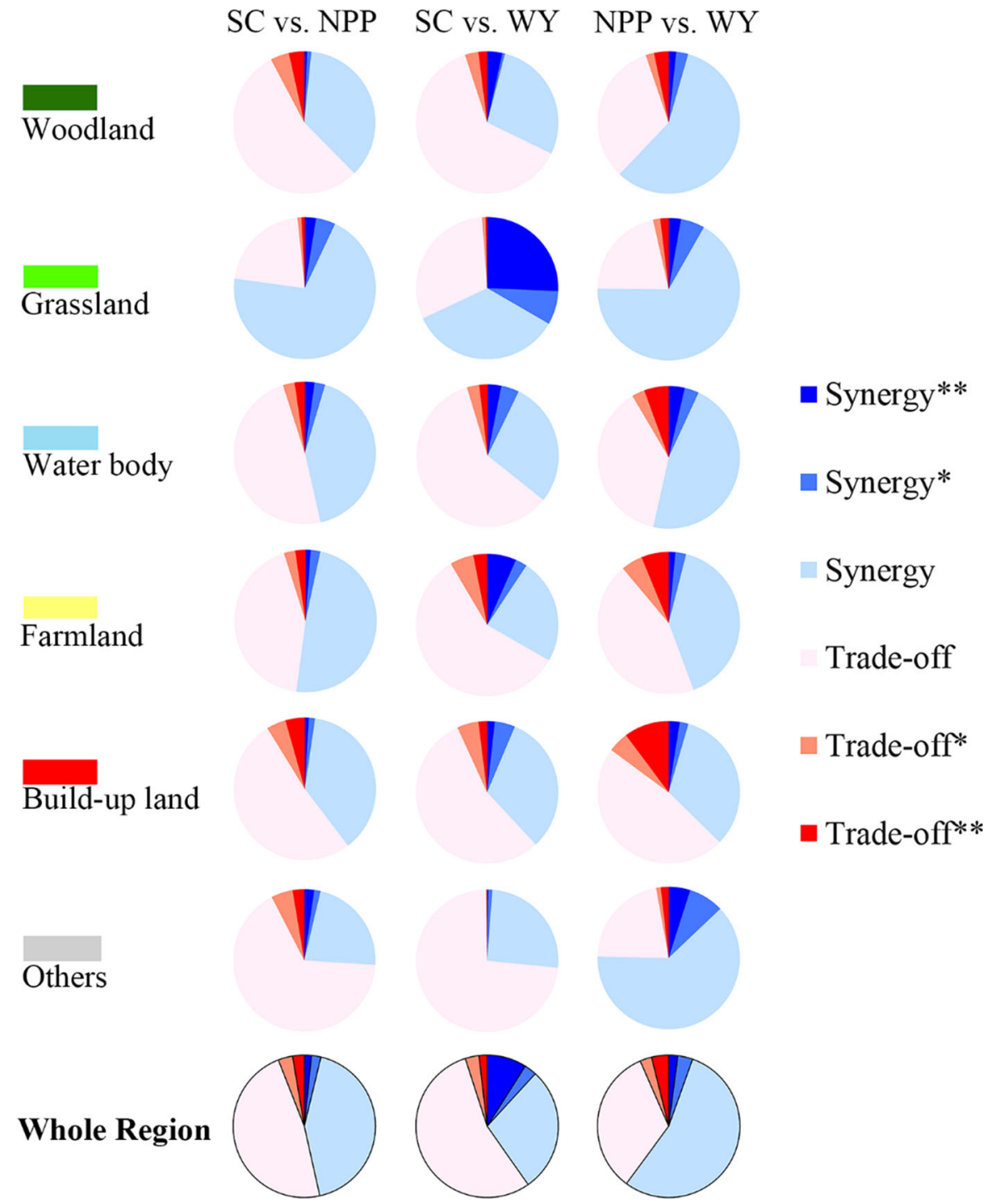


water yield (WY), from 2000 to 2013 in the Shaanxi province, China. The increase of SC and NPP in northern Shaanxi was mostly attributed to the largescale ecological construction projects, such as the Three-North Shelter Forest Program (TNSFP) and the Grain-for-Green Program (GFG). Especially, in the Yan River basin, the most extensive vegetation restoration projects have greatly helped enhance the soil conservation and boosted the increase of NPP (Xie et al. 2009; Su et al. 2012; Wang et al. 2015). Our results also showed that the WY across the whole region decreased, which is consistent with previous studies in the LP (Sun et al. 2006; Lü et al. 2012). The decrease likely resulted from the vegetation restoration projects (e.g., TNSFP, GFG and etc.), which increased the evapotranspiration, and consequently led to water shortage (Jackson et al. 2005), especially in the LP region. However, few studies revealed the spatial heterogeneity in regional WY. In our results, conversely, the WY in the northwestern LP increased over the past decade. This may owe to the significant increase of precipitation (PPT) in this region (see Appendix 2, Fig. A3), where although the evapotranspiration (ET) increased, the magnitude of its change did not exceed the increases in PPT. Furthermore, a majority of climate models are projecting an increase of PPT over the Yan River catchment (Wang et al. 2015). Nevertheless, further analysis is needed since recent growing literatures has been arguing that the variation of WY is not totally decided by the LULC change, but dominated by regional climate change and human activities (such as landscape engineering, terracing and the construction of check dams and reservoirs) (Feng et al. 2012; Wang et al. 2015).

Quantifying ecosystem services and their interactions at fine spatial and temporal scale benefits for management purposes

Our results demonstrated that trade-offs and synergies among ES are characterized with distinct spatial heterogeneity, instead of a fixed relationship. This is partly because scale plays an important role in estimating ES and analyzing their interactions (GretRegamey et al. 2014). For example, the space-for-time approach only revealed highly significant synergies among all the three ES in our study (see Appendix 1,

Table 4 Cohen's Kappa (K) agreement test for ES interactions identified by different methods

\begin{tabular}{|c|c|c|c|c|}
\hline & Methods & m5 & m6 & m7 \\
\hline \multirow{3}{*}{$\begin{array}{l}\hat{z} \\
\hat{z} \\
\dot{z} \\
\dot{\nu}\end{array}$} & m5 & & 0.039 & 0.333 \\
\hline & m6 & & & 0.442 \\
\hline & m7 & & & \\
\hline \multirow{3}{*}{$\frac{\sum}{\dot{D}}$} & m5 & & 0.196 & 0.197 \\
\hline & m6 & & & 0.229 \\
\hline & m7 & & & \\
\hline \multirow{3}{*}{$\begin{array}{l}\dot{z} \\
\dot{z} \\
\bar{z} \\
\bar{z}\end{array}$} & m5 & & 0.367 & 0.206 \\
\hline & m6 & & & 0.023 \\
\hline & m7 & & & \\
\hline
\end{tabular}

$0 \leq \mathrm{K} \leq 0.20$ indicates slight agreement, $0.20 \leq \mathrm{K} \leq 0.40$ indicates fair agreement, $0.41-0.60$ as moderate agreement, $0.61-0.80$ as substantial agreement, and 0.81-1.00 almost perfect agreement (Landis and Koch 1977; Schröter and Remme 2016) 
Table A1). However, spatially explicit methods (i.e., methods $\mathrm{m} 5, \mathrm{~m} 6$ and $\mathrm{m} 7$ described in Table 3) all revealed that ES interactions varied across locations or landscapes. This is not surprising because static methods at coarse scale (e.g., methods $\mathrm{m} 1$ and $\mathrm{m} 2$ described in Table 3) for inferring ES interactions often do not account for temporal and spatial variability in local drivers, such as political policies, socioeconomic decisions and the spatial distribution of physical geographic conditions (Renard et al. 2015; Hein et al. 2016; Tomscha and Gergel 2016). Consequently, ES pattern and interactions observed at the smaller scale may be hidden at larger scale (RaudseppHearne and Peterson 2016). Haase et al. (2012) compared interactions between ES at different spatial scales and pointed out that for planning purpose, only analysis at the grid scale is meaningful. We suggest that the static methods are suitable for small watershed and local scales, where landscapes are homogeneous; but can lead to misunderstanding at regional- and macro-scale. Though some other semi-static or semidynamic approaches incorporated landscape history into understanding ES interactions (e.g., $\mathrm{m} 4$ and $\mathrm{m} 5$ described in Table 3) (Haase et al. 2012; Tomscha and Gergel 2016), some of them may ignore the uncertainty in the changes of ES within a short time span. For instance, the change in modeled ES at two time points may very likely be dominated or overwhelmed by external environment (e.g., abrupt climate in one year). Consequently, an improper trade-off or synergy may be detected by applying these approaches. Thereby, apart from considering spatial variability to detect spatially explicit ES interactions, temporal variability over a longer-term is necessary to be considered in the analysis (Hein et al. 2016). Additionally, by comparing our method with other spatially explicit methods, we found moderate differences in spatial configuration of ES interactions depending on the method applied (see Appendix 2, Fig. A2). Kappa statistics for pairwise agreement of spatialized ES interactions showed mostly fair to moderate agreement. As discussed above, method $\mathrm{m} 5$ may ignore the possibility of abrupt and incomparable change in pairwise ES, and may consequently lead to misinterpretation of ES interactions. In addition, method $\mathrm{m} 6$ considered longer-term time series, and its result was similar to that in the spatio-temporal statistical method. However, the latter has the advantage of identifying ES interactions with different degrees (e.g., strong trade-offs, weak trade-offs, etc.), which would be helpful for decision-makers to prioritize land-use planning to optimize management outcomes.

Our analyses revealed that in grasslands in the arid and semi-arid area, relationships between ES tended to be synergies, while in artificial lands (e.g., built-up land and farmland) ES relationships tended to be trade-offs. Surprisingly, we found that ES in woodland were not likely present synergies. These results are of concern because emerging research revealed that extensive reforestation in the arid and semi-arid areas can lead to serious water shortage and create potential conflicting demands for water between the ecosystem and humans (Feng et al. 2016). This information may prompt us to rethink the rationality of planning trees for vegetation restoration in this arid and semi-arid area (Haslett et al. 2010; Goldstein et al. 2012; Fu et al. 2015). Besides, we found that in the LP, most LULC transition (from 2000 to 2013) were transferred into grassland (80.24\%, see Appendix 2, Fig. A4), instead of woodland (13.44\%). This information may also help overturn the claim that reforestation led to WY decrease in the northern LP since there was far less afforestation than expected, thereby supported our result regarding WY.

Opportunities and challenges in improving understanding of ES interactions

Our research highlights the need of integrating fine spatial scale and temporal dynamics of longer time frames in both ES and their drivers to better understand the trade-offs and synergies among multiple ES, especially in the regions where frequent and drastic change in LULC and climate occurred. The first reason is to avoid uncertainty or arbitrariness in analyzing ES change and their interactions at limited time points or over a short-term. As previously stated, abrupt climate in one certain year may lead to abnormal evaluation of ES. However, when modeling ES over a long-time series combining with statistical test, it would be robust to identify the change trend of each ES. Secondly, we argue that analysis over longer time series may help detect threshold or lag effect in the ES interactions. We know that some systems and processes are initially insensitive to environmental or human disturbance (such as climate change, LULC 
change, intensity of farming, and etc.), but after a certain threshold an ecosystem may change abruptly; other systems, may respond quickly to the disturbance without lagging (Fig. 8) (Fisher et al. 2009; RaudseppHearne et al. 2010). Studies toward this topic are rare, and our framework may benefit for detecting the possible threshold in ES interactions. Thirdly, analyzing ES and their interactions over long time series benefits from the increasing availability of spatial data (e.g., remote sensing and regular social-economic statistic data) and quantitative ES models. The remote sensing provides abundant spatio-temporal datasets covering large regions can make up for the lack of data in field observation/surveys (Ouyang et al. 2016), and thereby make it possible for ES change analysis at multiple spatio-temporal scales.

However, challenges still exist. The first challenge is the data quality (i.e., availability, completeness, uniformity). Non-uniform historical data may make the comparison difficult (Raudsepp-Hearne et al. 2010; Dallimer et al. 2015; Hein et al. 2016). For instance, the MODIS NDVI is important parameter for modeling NPP and WY in this text, but these datasets are only available since 2000 . This means if we want to reconstruct earlier historical NDVI datasets, it is necessary to carefully choose proper spatial resolution and guarantee the precision when seeking alternative remote sensing data. The second is that it would be difficult to model and spatialize some ES, for example, the cultural services. This difficulty is also partly because the spatial data for modeling these services are often unavailable.

Besides, our approach for modeling ES has several limitations. Though the models adopted in this study were all carefully chosen to be suitable for the study area, there are some inherent uncertainty regarding parameters input during the process of ES modeling. For example, the most important empirical parameter of the plant-available water coefficient $(w)$ in the Zhang et al's (2001) water yield model was assigned by the difference in ET among LULC types, which was based on their ability of extracting soil water. The model has been widely used and verified to be effective for the evaluation of annual WY (Brown et al. 2005; Lu et al. 2013; Zhang et al. 2015), but the calibration of $w$ for regional WY is still difficult. Meanwhile, we used substitution LULC data (LULC data in 2000, 2005, 2010, 2013) to model annual WY from 2000 to 2013 because of the limited dataset,

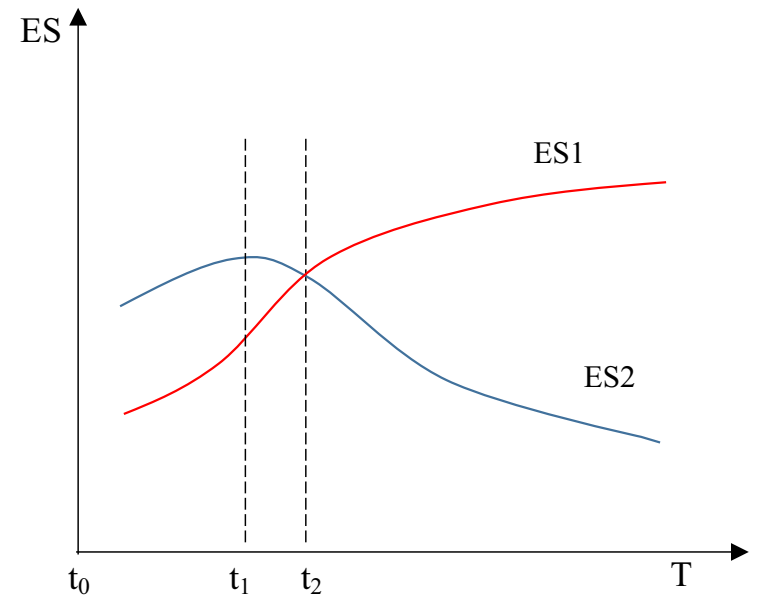

Fig. 8 Threshold in the process of ecosystem services interactions. The ES data chosen at different stages may outcome different results of ES interactions. For example, ES1 and ES2 may present synergy during $t_{0}-t_{1}$, while trade-off after $t_{1}$

which may make the temporal change of WY inapparently. Ideally, it would be perfect if annual LULC data were available. Besides, this WY model does not account for other key factors, such as vegetation characteristics, soil properties and topography, which may lead to underestimation of the ET and overestimation the annual WY (Zhang et al. 2008; Feng et al. 2012). Another limitation of this research lies in the interpretation on driving mechanism of ES interactions. Though we could identify the spatial patterns of ES interactions, it is still hard to explicitly figure out the causality among ES and their drivers (e.g., LULC change, climate change and regional hydrological condition, etc.). This information would be of importance for taking targeted engineering or conservation measures towards avoiding trade-offs in ES.

\section{Conclusions}

In summary, our study provides an integrative and spatially explicit method for assessing the interactions (i.e., trade-offs and synergies) among multiple ecosystem services (ES) by taking spatial and temporal dynamics simultaneously. Our results demonstrate that ES trade-offs and synergies vary across landscape, and differ among LULC types. Our study also highlights the importance of incorporating spatial statistics and long-term perspectives of ES in understanding ES interactions. Results from our research 
provide crucial information for decision-makers to determine priorities for the land-use planning or ecological restoration at broad scale to gain global optimizing results. This research also contributes to providing a framework for other researchers to conduct similar spatially explicit quantification of interactions among multiple ES in different contexts that aims to inform targeted land-use policy-making in regional ecosystem management.

Acknowledgements We thank Lei Jiao and Feng Yang for providing helpful discussions about this work. We also appreciate constructive comments from two anonymous reviewers that greatly improved this manuscript. This work was funded by the National Natural Science Foundation of China (41601182), the National Key Research and Development Plan of China (2016YFC0501601), the Key Project of Chinese Ministry of Education (15JJD790022), the National Social Science Foundation of China (14AZD094), the Fundamental Research Funds for the Central Universities (GK201603078) and the China Postdoctoral Science Foundation (2016M592743).

\section{References}

Anderson BJ, Armsworth PR, Eigenbrod F, Thomas CD, Gillings S, Heinemeyer A, Roy DB, Gaston KJ (2009) Spatial covariance between biodiversity and other ecosystem service priorities. J Appl Ecol 46(4):888-896

Bennett EM (2017) Research frontiers in ecosystem service science. Ecosystems 20(1):31-37

Bennett EM, Peterson GD, Gordon LJ (2009) Understanding relationships among multiple ecosystem services. Ecol Lett 12(12):1394-1404

Birkhofer K, Diehl E, Andersson J, Ekroos J, Früh-Müller A, Machnikowski F, Mader VL, Nilsson L, Sasaki K, Rundlöf M (2015) Ecosystem services-current challenges and opportunities for ecological research. Front Ecol Evol 2:87

Brown AE, Zhang L, McMahon TA, Western AW, Vertessy RA (2005) A review of paired catchment studies for determining changes in water yield resulting from alterations in vegetation. J Hydrol 310(1-4):28-61

Budyko MI (1974) Climate and life. Academic Press, San Diego

Butler JRA, Wong GY, Metcalfe DJ, Honzak M, Pert PL, Rao N, van Grieken ME, Lawson T, Bruce C, Kroon FJ, Brodie JE (2013) An analysis of trade-offs between multiple ecosystem services and stakeholders linked to land use and water quality management in the Great Barrier Reef, Australia. Agric Ecosyst Environ 180:176-191

Cai C, Ding S, Shi Z, Huang L, Zhang G (2000) Study of applying USLE and geographical information system IDRISI to predict soil erosion in small watershed. J Soil Water Conserv 14(2):19-24

Costanza R, Fisher B, Mulder K, Liu S, Christopher T (2007) Biodiversity and ecosystem services: a multi-scale empirical study of the relationship between species richness and net primary production. Ecol Econ 61(2-3):478-491
Daily GC, Polasky S, Goldstein J, Kareiva PM, Mooney HA, Pejchar L, Ricketts TH, Salzman J, Shallenberger R (2009) Ecosystem services in decision making: time to deliver. Front Ecol Environ 7(1):21-28

Dallimer M, Davies ZG, Diaz-Porras DF, Irvine KN, Maltby L, Warren PH, Armsworth PR, Gaston KJ (2015) Historical influences on the current provision of multiple ecosystem services. Glob Environ Change 31:307-317

de Groot RS, Alkemade R, Braat L, Hein L, Willemen L (2010) Challenges in integrating the concept of ecosystem services and values in landscape planning, management and decision making. Ecol Complex 7(3):260-272

de Groot RS, Wilson MA, Boumans RMJ (2002) A typology for the classification, description and valuation of ecosystem functions, goods and services. Ecol Econ 41(3):393-408

Deng X, Li Z, Gibson J (2016) A review on trade-off analysis of ecosystem services for sustainable land-use management. J Geog Sci 26(7):953-968

ESRI I (2013) ArcGIS: release 10.2. Esri Inc, Redmond

Feng X, Fu B, Piao S, Wang S, Ciais P, Zeng Z, Lu Y, Zeng Y, Li Y, Jiang X, Wu B (2016) Revegetation in China[rsquor]s Loess Plateau is approaching sustainable water resource limits. Nat Clim Change 6(11):1019-1022

Feng XM, Sun G, Fu BJ, Su CH, Liu Y, Lamparski H (2012) Regional effects of vegetation restoration on water yield across the Loess Plateau, China. Hydrol Earth Syst Sci 16(8):2617-2628

Fischer G, Nachtergaele F, Prieler S, Van Velthuizen H, Verelst L, Wiberg D (2008) Global agro-ecological zones assessment for agriculture (GAEZ 2008). IIASA, Laxenburg

Fisher B, Turner RK, Morling P (2009) Defining and classifying ecosystem services for decision making. Ecol Econ 68(3):643-653

Foley JA, Defries R, Asner GP, Barford C, Bonan G, Carpenter SR, Chapin FS, Coe MT, Daily GC, Gibbs HK, Helkowski JH, Holloway T, Howard EA, Kucharik CJ, Monfreda C, Patz JA, Prentice IC, Ramankutty N, Snyder PK (2005) Global consequences of land use. Science 309(5734):570-574

Fu B, Liu Y, Lu Y, He C, Zeng Y, Wu B (2011) Assessing the soil erosion control service of ecosystems change in the Loess Plateau of China. Ecol Complex 8(4):284-293

Fu B, Zhang L, Xu Z, Zhao Y, YongpingWei Skinner D (2015) Ecosystem services in changing land use. J Soils Sediments 15(4):833-843

Goldstein JH, Caldarone G, Duarte TK, Ennaanay D, Hannahs N, Mendoza G, Polasky S, Wolny S, Daily GC (2012) Integrating ecosystem-service tradeoffs into land-use decisions. Proc Natl Acad Sci USA 109(19):7565-7570

Gret-Regamey A, Weibel B, Bagstad KJ, Ferrari M, Geneletti D, Klug H, Schirpke U, Tappeiner U (2014) On the effects of scale for ecosystem services mapping. PLoS ONE 9(12):e112601

Haase D, Schwarz N, Strohbach M, Kroll F, Seppelt R (2012) Synergies, Trade-offs, and Losses of Ecosystem Services in Urban Regions: an Integrated Multiscale Framework Applied to the Leipzig-Halle Region, Germany. Ecol Soc 17(3)

Haberl H, Erb K-H, Krausmann F (2013) Global human appropriation of net primary production (HANPP). Retrieved from http://www.eoearth.org/view/article/ 153031 
Hamon WR (1963) Computation of direct runoff amounts from storm rainfall. International Association of Scientific Hydrology Publication

Haslett JR, Berry PM, Bela G, Jongman RHG, Pataki G, Samways MJ, Zobel M (2010) Changing conservation strategies in Europe: a framework integrating ecosystem services and dynamics. Biodivers Conserv 19(10): 2963-2977

Hein L, van Koppen CSA, van Ierland EC, Leidekker J (2016) Temporal scales, ecosystem dynamics, stakeholders and the valuation of ecosystems services. Ecosyst Serv 21:109-119

Hu H, Fu B, Lü Y, Zheng Z (2014) SAORES: a spatially explicit assessment and optimization tool for regional ecosystem services. Landscape Ecol 30(3):547-560

Jackson RB, Jobbágy EG, Avissar R, Roy SB, Barrett DJ, Cook CW, Farley KA, le Maitre DC, McCarl BA, Murray BC (2005) Trading water for carbon with biological carbon sequestration. Science 310(5756): 1944

Jia X, Fu B, Feng X, Hou G, Liu Y, Wang X (2014) The tradeoff and synergy between ecosystem services in the Grain-forGreen areas in Northern Shaanxi, China. Ecol Ind 43:103-113

Landis JR, Koch GG (1977) The measurement of observer agreement for categorical data. Biometrics, 159-174

Lee H, Lautenbach S (2016) A quantitative review of relationships between ecosystem services. Ecol Ind 66:340-351

Li S (2014) The geography of ecosystem services. Science Press, Beijing

Li Y, Zhang L, Yan J, Wang P, Hu N, Cheng W, Fu B (2017) Mapping the hotspots and coldspots of ecosystem services in conservation priority setting. J Geog Sci 27(6):681-696

Liu J, Kuang W, Zhang Z, Xu X, Qin Y, Ning J, Zhou W, Zhang S, Li R, Yan C, Wu S, Shi X, Jiang N, Yu D, Pan X, Chi W (2014) Spatiotemporal characteristics, patterns, and causes of land-use changes in China since the late 1980s. J Geog Sci 24(2):195-210

Lu N, Sun G, Feng X, Fu B (2013) Water yield responses to climate change and variability across the North-South Transect of Eastern China (NSTEC). J Hydrol 481:96-105

Lü Y, Fu B, Feng X, Zeng Y, Liu Y, Chang R, Sun G, Wu B (2012) A policy-driven large scale ecological restoration: quantifying ecosystem services changes in the Loess Plateau of China. PLoS ONE 7(2):e31782

Lufafa A, Tenywa M, Isabirye M, Majaliwa M, Woomer P (2003) Prediction of soil erosion in a Lake Victoria basin catchment using a GIS-based Universal Soil Loss model. Agric Syst 76(3):883-894

Maes J, Paracchini ML, Zulian G, Dunbar MB, Alkemade R (2012) Synergies and trade-offs between ecosystem service supply, biodiversity, and habitat conservation status in Europe. Biol Conserv 155:1-12

MEA (2005) Ecosystems and human well-being: current state and trends. Island Press, Washington, DC, pp 829-838

Naidoo R, Balmford A, Costanza R, Fisher B, Green RE, Lehner B, Malcolm TR, Ricketts TH (2008) Global mapping of ecosystem services and conservation priorities. Proc Natl Acad Sci USA 105(28):9495-9500

Nelson E, Mendoza G, Regetz J, Polasky S, Tallis H, Cameron DR, Chan KMA, Daily GC, Goldstein J, Kareiva PM, Lonsdorf E, Naidoo R, Ricketts TH, Shaw MR (2009)
Modeling multiple ecosystem services, biodiversity conservation, commodity production, and tradeoffs at landscape scales. Front Ecol Environ 7(1):4-11

Ouyang Z, Zheng H, Xiao Y, Polasky S, Liu J, Xu W, Wang Q, Zhang L, Xiao Y, Rao E (2016) Improvements in ecosystem services from investments in natural capital. Science 352(6292):1455-1459

Potter CS, Randerson JT, Field CB, Matson PA, Vitousek PM, Mooney HA, Klooster SA (1993) Terrestrial ecosystem production: a process model based on global satellite and surface data. Global Biogeochem Cycles 7(4):811-841

Qin K, Li J, Yang X (2015) Trade-off and synergy among ecosystem services in the Guanzhong-Tianshui Economic Region of China. Int $\mathrm{J}$ Environ Res Public Health 12(11):14094-14113

Qiu J, Turner MG (2013) Spatial interactions among ecosystem services in an urbanizing agricultural watershed. Proc Natl Acad Sci USA 110(29):12149-12154

Qiu J, Turner MG (2015) Importance of landscape heterogeneity in sustaining hydrologic ecosystem services in an agricultural watershed. Ecosphere 6(11):229

Raudsepp-Hearne C, Peterson GD (2016) Scale and ecosystem services: how do observation, management, and analysis shift with scale-lessons from Québec. Ecol Soc 21(3):16

Raudsepp-Hearne C, Peterson GD, Bennett EM (2010) Ecosystem service bundles for analyzing tradeoffs in diverse landscapes. Proc Natl Acad Sci USA 107(11):5242-5247

Renard D, Rhemtulla JM, Bennett EM (2015) Historical dynamics in ecosystem service bundles. Proc Natl Acad Sci 112(43):13411-13416

Renard KG, Foster G, Weesies G, McCool D, Yoder D (1997) Predicting soil erosion by water: a guide to conservation planning with the Revised Universal Soil Loss Equation (RUSLE). United States Department of Agriculture, Washington, DC

Rodriguez JP, Beard TD Jr, Bennett EM, Cumming GS, Cork SJ, Agard J, Dobson AP, Peterson GD (2006) Trade-offs across space, time, and ecosystem services. Ecol Soc 11(1):28

Schröter M, Remme RP (2016) Spatial prioritisation for conserving ecosystem services: comparing hotspots with heuristic optimisation. Landscape Ecol 31:431-450

Sharp R, Tallis H, Ricketts T, Guerry A, Wood S, ChaplinKramer R, Nelson E, Ennaanay D, Wolny S, Olwero N, Vigerstol K, Pennington D, Mendoza G, Aukema J, Foster J, Forrest J, Cameron D, Arkema K, Lonsdorf E, Kennedy C, Verutes G, Kim CK, Guannel G, Papenfus M, Toft J, Marsik M, Bernhardt J, Griffin R, Glowinski K, Chaumont N, Perelman A, Lacayo MM, L, Hamel P, Vogl AL, Rogers L, Bierbower W (2016) InVEST+VERSION+User's Guide. The Natural Capital Project, Stanford University, University of Minnesota, The Nature Conservancy, and World Wildlife Fund

Su C, Fu B (2013) Evolution of ecosystem services in the Chinese Loess Plateau under climatic and land use changes. Global Planet Change 101:119-128

$\mathrm{Su}$ C, Fu B, He C, Lu Y (2012) Variation of ecosystem services and human activities: a case study in the Yanhe Watershed of China. Acta Oecologica 44:46-57

Sun G, McNulty SG, Lu J, Amatya DM, Liang Y, Kolka R (2005) Regional annual water yield from forest lands and 
its response to potential deforestation across the southeastern United States. J Hydrol 308(1):258-268

Sun G, Zhou G, Zhang Z, Wei X, McNulty SG, Vose JM (2006) Potential water yield reduction due to forestation across China. J Hydrol 328(3-4):548-558

Thompson JR, Lambert KF, Foster DR, Broadbent EN, Blumstein M, Almeyda Zambrano AM, Fan Y (2016) The consequences of four land-use scenarios for forest ecosystems and the services they provide. Ecosphere 7(10):e01469

Tomscha SA, Gergel SE (2016) Ecosystem service trade-offs and synergies misunderstood without landscape history. Ecol Soc 21(1):43

Ungaro F, Zasada I, Piorr A (2014) Mapping landscape services, spatial synergies and trade-offs. A case study using variogram models and geostatistical simulations in an agrarian landscape in North-East Germany. Ecol Ind 46:367-378

Wang J, Lü Y, Zeng Y, Zhao Z, Zhang L, Fu B (2014) Spatial heterogeneous response of land use and landscape functions to ecological restoration: the case of the Chinese loess hilly region. Environ Earth Sci 72(7):2683-2696

Wang S, Fu B, Piao S, Lü Y, Ciais P, Feng X, Wang Y (2015) Reduced sediment transport in the Yellow River due to anthropogenic changes. Nat Geosci 9(1):38-41

Wischmeier W, Smith D (1965) Rainfall-Erosion Losses From Cropland East of the Rocky Mountains, Guide for Selection of Practices for Soil and Water Conservation. Agriculture Handbook 282

Xie H, Li R, Yang Q, Li J, Liang W (2009) Effect of returning farmland to forest (pasture) and changes of precipitation on soil erosion in the Yanhe basin. Sci Agric Sin 42(2):569-576

Zhang L, Dawes W, Walker G (2001) Response of mean annual evapotranspiration to vegetation changes at catchment scale. Water Resour Res 37(3):701-708

Zhang L, Fu B, Lü Y, Zeng Y (2015) Balancing multiple ecosystem services in conservation priority setting. Landscape Ecol 30(3):535-546

Zhang L, Hickel K, Dawes W, Chiew FH, Western A, Briggs P (2004) A rational function approach for estimating mean annual evapotranspiration. Water Resour Res 40:W02502

Zhang M, Wei X, Sun P, Liu S (2012) The effect of forest harvesting and climatic variability on runoff in a large watershed: the case study in the Upper Minjiang River of Yangtze River basin. J Hydrol 464-465:1-11

Zhang XP, Zhang L, McVicar TR, Van Niel TG, Li LT, Li R, Yang Q, Wei L (2008) Modelling the impact of afforestation on average annual streamflow in the Loess Plateau, China. Hydrol Process 22(12):1996-2004

Zhao Y, Yu X, Zheng J, Wu Q (2012) Quantitative effects of climate variations and land-use changes on annual streamflow in Chaobai river basin. Trans Chin Soc Agric Eng 28(22):252-260

Zhu W, Pan Y, He H, Yu D, Hu H (2006) Simulation of maximum light use efficiency for some typical vegetation types in China. Chin Sci Bull 51(4):457-463

Zurlini G, Jones KB, Riitters KH, Li B-L, Petrosillo I (2014) Early warning signals of regime shifts from cross-scale connectivity of land-cover patterns. Ecol Ind 45:549-560 